\title{
Hepatitis c antibody testing in African American and Hispanic men in New York City with prostate biopsy
}

\author{
Annika Krystyna ${ }^{1 *}$, Divya Kumari', Robert Tenney ${ }^{1}$, Radomir Kosanovic ${ }^{1}$, Tarang Safi', William Matthew Briggs ${ }^{1}$, Karen Hennessey ${ }^{2}$, \\ Michael Skelly², Eduardo Enriquez', Jean Lajeune', Wasim Ghani' and Murray David Schwalb \\ *Correspondence: Ana.Osansky@nychhc.org \\ ${ }^{1}$ Lincoln Medical and Mental Health Center, Department of Urology, 234 E. 149th Street STE 2 A7 Bronx, NY 10451, USA. \\ 2Lincoln Medical and Mental Health Center, Department of Infectious Diseases, 234 E. 149th Street STE 2A5 Bronx, NY 10451 , USA.
}

\begin{abstract}
Background: An analysis of the Prostate Cancer Database Project previously identified an association between hepatitis C antibody testing and prostate cancer (Pca).

Methods: The records of 864 African American (AA) and Hispanic men from January 1, 2000, thru July 31, 2011 with both prostate biopsy and hepatitis $\mathrm{C}$ antibody testing were examined. Chi-squared tests, T-tests of difference and logistic regression models were used to interpret data. A skill plot was used to integrate receiver operating curves and optimal cut-off for PSA in accordance with Bayesian theory.

Results: Seventy percent of AA men and 52\% of Hispanic men with hepatitis C antibody testing had Pca, while $68 \%$ of AA and $70 \%$ of Hispanic men with hepatitis C antibody detected had Pca. African American men had significantly higher rates of Pca, hepatitis $\mathrm{C}$ antibody detected, HIV, and higher cancer stage at diagnosis when compared to Hispanic men. Prostate cancer was more likely to metastasize despite average histological Gleason scores of less than 7 and was not related to number of cancer containing cores at biopsy. PSA did not meet criteria required of standard screening tests to detect Pca in this patient population.

Conclusions: In New York City, African American and Hispanic men referred for prostate biopsy with a history of hepatitis C antibody detection or indication for testing have the highest rates of Pca detected in any group identified to date, with high rates of metastatic disease at presentation independent of PSA, histological Gleason scores and number of cores containing cancer at diagnostic biopsy. The presence of serum hepatitis $\mathrm{C}$ antibody significantly increases odds of Pca.
\end{abstract}

Keywords: Prostatic neoplasm, hepatitis, hepatitis C, HCVab, antibody, African American, Hispanic, men, gleason, psa

\section{Background}

In 2009, the Prostate Cancer Database Project at New York Health and Hospitals Corporation began collecting information on men with transrectal prostate biopsy at two hospitals in New York City serving patients with socioeconomic disparities. To date, the database contains information for nearly three thousand men over a twelve year period at two hospitals located in Bronx, New York. The population is comprised mostly of African American and Hispanic men from over sixty documented countries of origin. The initial goals of database creation were to establish risks, benefits and selection criteria for transrectal prostate biopsy. In our search for risk factors for prostate cancer, our previous research revealed an association between hepatitis $\mathrm{C}$ antibody and prostate cancer during preliminary analysis for prostate cancer risk factors [1]. As the database expanded we collected more information and describe our findings in this report.

\section{Methods}

The electronic records of men referred for prostate biopsy at two institutions between January 1, 2000, and July 31, 2011 were examined retrospectively for the presence of hepatitis $\mathrm{C}$ antibody testing. The study was approved by the Lincoln Hospital Institutional Review Board and the Health and Hospitals
Corporation Central Office for Research. There were 864 men with both prostate biopsy and hepatitis $C$ antibody testing. One African American man was excluded for an inconclusive biopsy result and 28 men who were not African American or Hispanic were excluded from further analysis due to multiple significant differences based on race. Data was calculated using SPSS version 16.0.2. Chi-squared tests were used to determine if there were differences between African American and Hispanic men (Table 1). T-tests of difference were used to examine PSA and histological grade between racial groups (Table 2). A skill plot $[2,3]$ was used to integrate receiver operating curves and optimal cut-off for PSA data in accordance with Bayesian theory (Figure 1).

\section{Results}

African American men $(n=226)$ and Hispanic men $(n=610)$ with prostate biopsy and hepatitis $C$ antibody testing had significant rates of HIV, hepatitis $C$ antibody detection and smoking. These rates were also significantly higher in African American men when compared to Hispanic men (Table 1). Prostate cancer occurred in 68\% (40/59) of African American and 70\% (26/37) of Hispanic men with hepatitis $C$ antibody detected. When controlling for age, men of either race with hepatitis $C$ antibody present had significantly increased odds of Pca OR 62 (95\% 
Krystyna et al. Oncology Discovery 2013,

http://www.hoajonline.com/journals/pdf/2052-6199-1-1.pdf

doi: 10.7243/2052-6199-1-1

Table 1. Characteristics and Comparison of African American and Hispanic Men.

\begin{tabular}{|c|c|c|c|c|c|}
\hline \multicolumn{3}{|c|}{ African Americans } & \multicolumn{3}{|c|}{ Hispanics } \\
\hline Hospital & $\mathbf{N}$ & $\%$ & $\mathbf{N}$ & $\%$ & P-value \\
\hline Institution 1 & 36 & ( 15.9$)$ & 469 & $(76.9)$ & $1.16 \mathrm{e}-57$ \\
\hline Institution 2 & 190 & $(84.1)$ & 141 & $(23.1)$ & - \\
\hline \multicolumn{6}{|c|}{ ProstateCancer } \\
\hline No & 99 & $(30)$ & 244 & $(48.3)$ & $1.44 \mathrm{e}-07$ \\
\hline Yes & 231 & $(70)$ & 261 & - & $(51.7)$ \\
\hline \multicolumn{6}{|c|}{ ProstateCancer w/HCVAb } \\
\hline No & 19 & $(32.2)$ & 11 & $(29.7)$ & 0.825 \\
\hline Yes & 40 & $(67.8)$ & 26 & - & $(70.3)$ \\
\hline \multicolumn{6}{|c|}{ ProstateCancer w/o HCVAb } \\
\hline No & 80 & $(29.5)$ & 233 & $(49.8)$ & $7.00 \mathrm{e}-07$ \\
\hline Yes & 191 & $(70.5)$ & 235 & - & $(50.2)$ \\
\hline \multicolumn{6}{|c|}{ Hepatitis C Antibody } \\
\hline No & 272 & $(82.2)$ & 468 & $(92.7)$ & $3.22 \mathrm{e}-06$ \\
\hline Yes & 59 & $(17.8)$ & 37 & - & $(7.33)$ \\
\hline \multicolumn{6}{|l|}{ HIV } \\
\hline No & 70 & $(76.1)$ & 240 & $(95.2)$ & $1.38 \mathrm{e}-07$ \\
\hline Yes & 22 & $(23.9)$ & 12 & - & $(4.76)$ \\
\hline \multicolumn{6}{|l|}{ Smoking } \\
\hline No & 115 & $(40.9)$ & 235 & $(50.1)$ & 0.016 \\
\hline Yes & 166 & $(59.1)$ & 234 & - & $(49.9)$ \\
\hline \multicolumn{6}{|c|}{ Clinical Group ${ }^{*}$ Preoperative } \\
\hline I & 55 & ( 32.9$)$ & 98 & $(44.5)$ & 0.019 \\
\hline IIA & 50 & ( 29.9 ) & 62 & - & $(28.2)$ \\
\hline IIB & 34 & $(20.4)$ & 40 & - & $(18.2)$ \\
\hline III & 2 & $(1.20)$ & 0 & - & $(0)$ \\
\hline IV & 26 & $(15.6)$ & 19 & - & $(8.64)$ \\
\hline Unknown & 0 & $(0)$ & 1 & - & $(0.454)$ \\
\hline \multicolumn{6}{|c|}{ Clinical Group ${ }^{*}$ Postoperative } \\
\hline I & 0 & $(0)$ & 0 & $(0)$ & 0.101 \\
\hline IIA & 0 & $(0)$ & 4 & - & $(6.90)$ \\
\hline IIB & 14 & $(50)$ & 36 & - & $(62.1)$ \\
\hline III & 12 & $(42.9)$ & 15 & - & $(25.9)$ \\
\hline IV & 2 & $(7.14)$ & 3 & - & $(5.17)$ \\
\hline
\end{tabular}

${ }^{\star}$ Staging based on American Joint Committee Meeting on Cancer 2002 Guidelines.

Table 2. Comparison of PSA and Prostate Biopsy Characteristics Between African American and Hispanic Men.

\begin{tabular}{lccccccc}
\hline African Americans & \multicolumn{7}{c}{ Hispanics } \\
\hline Median & Mean & SD & Median & Mean & SD & & P-value \\
\hline $\begin{array}{l}\text { Age (Years) } \\
\text { PSA (ng/dL) }\end{array}$ & 69 & 69 & $(9.8)$ & 71 & 71 & $(9.5)$ & 0.047 \\
$\begin{array}{l}\text { PSA with Pca } \\
\text { (ng/dL) }\end{array}$ & 9.23 & 31.4 & $(112)$ & 5.26 & 19.0 & $(92.1)$ & 0.112 \\
$\begin{array}{l}\text { PSA without Pca } \\
\text { (ng/dl) }\end{array}$ & 5.80 & 93.2 & $(137)$ & 6.01 & 32.7 & $(132)$ & 0.45 \\
$\begin{array}{l}\text { Total Biopsy } \\
\text { Cores }\end{array}$ & 12 & 12.6 & $(6.2)$ & 12 & 12.5 & $(4.6)$ & 0.984 \\
$\begin{array}{l}\text { No. Cores with } \\
\text { Cancer }\end{array}$ & 3 & 4.63 & $(3.77)$ & 3 & 4.46 & $(3.9)$ & 0.727 \\
$\begin{array}{l}\text { Primary Pattern } \\
\text { Secondary Pattern }\end{array}$ & 3 & 3.25 & $(0.805)$ & 3 & 3.20 & $(0.611)$ & 0.437 \\
Gleason Score & 6.5 & 6.59 & $(1.47)$ & 6 & 6.59 & $(1.04)$ & 0.972 \\
\hline
\end{tabular}

$\mathrm{Cl} 2.2$ to $1900 ; \mathrm{p}=0.012)$. In those men where no hepatitis $\mathrm{C}$ antibody was detected, the rate of prostate cancer in African

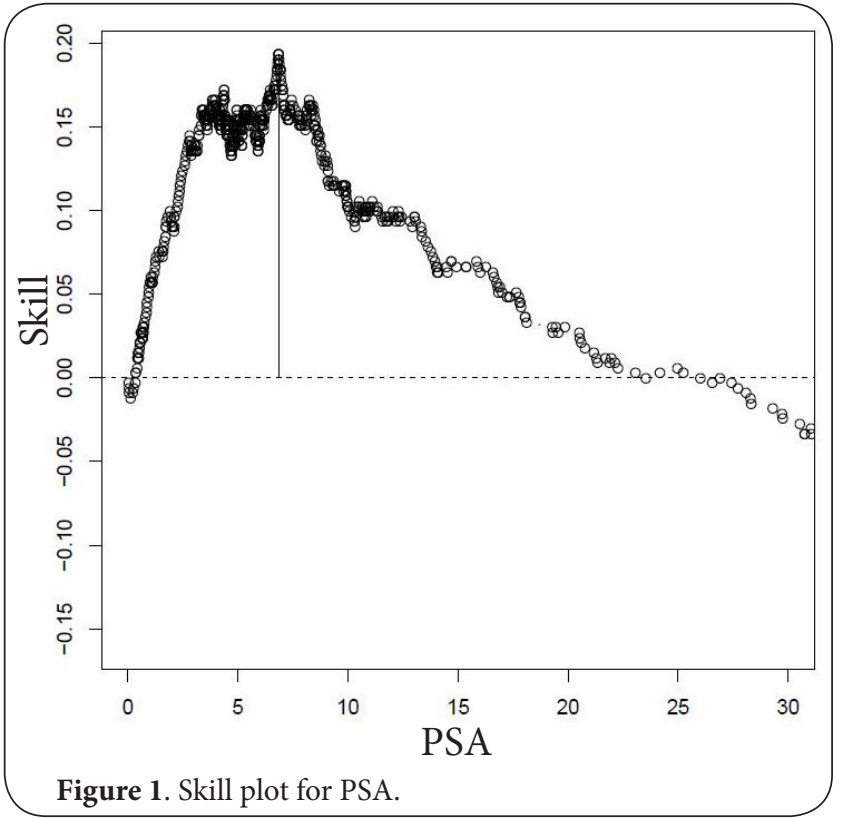

American men persisted at 70.5\% (191/271) and decreased to $50.2 \%$ (235/468) in Hispanic men.

African American men tested for hepatitis C antibody were significantly more likely to have prostate cancer spread beyond the prostate at the time of diagnosis when compared to Hispanic men with the same hepatitis testing, however, the rates of spread beyond the prostate is still higher than expected. Stage T3 and metastatic cancer were seen at initial presentation in $16.8 \%(28 / 167)$ of AA and $8.6 \%(19 / 220)$ of Hispanic men with indication for hepatitis $C$ testing. In men undergoing prostatectomy for presumed prostate-confined cancers, 50.0\% (14/28) of African American and 31.0\% (18/58) of Hispanic men had spread beyond the prostate evident by surgical pathology (Table 1). Although clinically these cancers were more likely to spread, histological Gleason scores averaged less than 7 and fewer than half of all diagnostic prostate biopsy cores contained cancer (Table 2). Age remained significant as the incidence of Pca increased with increasing age OR 1.03 per year (95\% Cl 1.01 to $1.05 ; \mathrm{p}=0.006)$.

In all statistical models of PSA calculation, the presence of hepatitis $C$ antibody remained independent and had no relationship to PSA levels. The effect of PSA was not different between African American and Hispanic men $(p=0.65)$. Since men were referred for prostate biopsy at a time when biopsy was suggested for men with PSA values over $4 \mathrm{ng} /$ $\mathrm{mL}$, we evaluated PSA to determine if there was any utility in this specific population of African American and Hispanic men with hepatitis $C$ antibody testing. A skill plot which incorporates receiver operating curves (Figure 1) [2,3] shows us that tests with skill to predict disease will have points that fall above the horizontal line when cancers are found more often than no cancer. When considering PSA as a screening test for this population, the best predictive ability occurred 
in the region of PSA values of 0.35 to $26 \mathrm{ng} / \mathrm{dL}$. Since this range encompassed most men who would be screened for early detection of prostate cancer at their doctor's office, the optimal cut-off was calculated and occurred at PSA $6.85 \mathrm{ng} /$ $\mathrm{dL}$, with sensitivity $55 \%$, specificity $72 \%$, accuracy $63 \%$ and OR $3.1\left(95 \% \mathrm{Cl} 2.28\right.$ to $\left.4.25 ; \mathrm{p}=1.0 \times 10^{-12}\right)$.

\section{Discussion}

This paper describes a very specific population of men with the unique characteristic of having hepatitis $C$ testing, which is ordered in patients with clinical reasons to suspect hepatitis $C$ exposure. Since hepatitis $C$ testing is not routinely performed in any age group, and the presence of this testing itself is significant, particularly in these men where the average age was approximately 70 years, where routine testing for the virus is not recommended. Elevation of liver transaminases is the most likely explanation as to why this testing was ordered and high rates of prostate cancer in men without hepatitis $C$ antibody present suggest there may be a relationship between the risk factors for hepatitis $\mathrm{C}$ exposure and prostate cancer pathogenesis.

Hepatitis $C$ has been linked to direct exposure to infected blood through transfusions [8], intravenous drug abuse [9], tattooing [10], sexual exposure [11] and inhalational cocaine use, through the sharing of nasal straws [12]. In men with evidence of hepatitis $C$ antibody the approximate $70 \%$ rate of prostate cancer raises the question of hepatitis $C$ as one potential causal mechanism for prostate cancer. However, coinfection with an infectious agent that is yet to be discovered is also a plausible hypothesis: The presence of high risk behaviors in these men is evident by the higher than expected rates of HIV and hepatitis in these men. In the African American group $23.9 \%$ had HIV and $17.8 \%$ had hepatitis $C$ antibody present, while in the Hispanic group 4.8\% had HIV and 7.3\% had hepatitis $\mathrm{C}$ antibody. One can infer the African American group had higher rates of risk taking behaviors based on the rates of HIV and hepatitis C exposure. These men also have the highest rates of prostate cancer identified in literature to date. It is also notable that prostate cancer in these men appears to be more aggressive with higher than expected rates of spread beyond the prostate then one would expect with an average Gleason score less than 7.

Although we were not the first group to study hepatitis $C$ exposure as a risk factor for prostate cancer, we were the first to find an association. Our ability to detect hepatitis $C$ and the way research was conducted had an important impact. Studies which previously excluded hepatitis $C$ were largely performed before 2000 on populations where not all patients had hepatitis $C$ testing and were subject to human reporting. Prior to 1992, testing (EIA-1) had sensitivity between $10 \%$ and $80 \%$ and was designed to avoid false-positive results as the test was thought to have $100 \%$ specificity [4]. Sensitivity increased to $95 \%$ in 1992 [5] (EIA-2) and to 97\% in 1997 [6] (EIA-3). There is currently no test with $100 \%$ sensitivity and specificity for the detection of hepatitis $C$, although polymerase chain reaction (PCR) detects viral RNA but is limited by technical errors [7]. Since our database contains laboratory results after 1999 we had the benefit of studying hepatitis C antibody at a time after technology had evolved, without having to rely on patient questionnaires.

Prostate specific antigen did not meet standard statistical screening test requirements to detect prostate cancer in this specific group of men. In these men the skill of PSA fell in the region of 0.35 to $26 \mathrm{ng} / \mathrm{mL}$, encompassing men who wish to be screened for early detection of prostate cancer. The optimal cut-off for this population occurred at PSA value $6.85 \mathrm{ng} / \mathrm{mL}$, however the accuracy using this cut off is only $63 \%$ and committing to this cut off as a screening guideline would cause many cases of prostate cancer to be missed in these men (Figure 1).

However, the presence of hepatitis $C$ antibody increased odds of prostate cancer significantly. Although our research continues to suggest increased odds of prostate cancer with hepatitis $\mathrm{C}$ antibody detection, our data concerning HIV and prostate cancer odds remain indeterminate ${ }^{1}$. We are currently investigating this. Although smoking appears to increase the risk of prostate cancer, when performing multivariate analysis, hepatitis $C$ antibody presence or testing weighed so heavily that smoking itself did not appear to be a risk factor for men in this study. However, this part of our study is limited to the subjective reporting of patients and cannot be objectively measured.

\section{Conclusions}

African American and Hispanic men referred for prostate biopsy with a history of hepatitis $\mathrm{C}$ antibody detection or indication for testing have the highest rates of prostate cancer detected in any group identified to date, with high rates of metastatic disease at presentation independent of PSA, histological Gleason scores and number of cores containing cancer at diagnostic biopsy. The presence of hepatitis $C$ antibody significantly increased odds of prostate cancer.

\section{Competing interests}

The authors declare that they have no competing interests.

\section{Publication history}

Received: 29-Jan-2013 Revised: 12-Feb-2013

Accepted: 19-Feb-2013 Published: 11-Mar-2013

\section{References}

1. Krystyna A, Safi T, Briggs WM and Schwalb MD: Correlation of hepatitis $C$ and prostate cancer, inverse correlation of basal cell hyperplasia or prostatitis and epidemic syphilis of unknown duration. Int Braz J Urol 2011, 37:223-9; discussion 230. | Article | PubMed

2. Briggs $W$ and Ruppert D: Assessing the skill of yes/no predictions. Biometrics 2005, 61:799-807. I Article I PubMed

3. Briggs WM and Zaretzki R: The Skill Plot: a graphical technique for evaluating continuous diagnostic tests. Biometrics 2008, 64:250-6; discussion 256-61. I Article I PubMed

4. Kuo G, Choo QL, Alter HJ, Gitnick GL, Redeker AG, Purcell RH, Miyamura 
Krystyna et al. Oncology Discovery 2013,

T, Dienstag JL, Alter MJ, Stevens CE and et al.: An assay for circulating antibodies to a major etiologic virus of human non-A, non-B hepatitis. Science 1989, 244:362-4. | Article I PubMed

5. Alter HJ: New kit on the block: evaluation of second-generation assays for detection of antibody to the hepatitis C virus. Hepatology 1992, 15:350-3. | Article | PubMed

6. Gretch DR: Diagnostic tests for hepatitis C. Hepatology 1997, 26:43S-47S | Article | PubMed

7. Dore GJ, Kaldor JM and McCaughan GW: Systematic review of role of polymerase chain reaction in defining infectiousness among people infected with hepatitis C virus. BMJ 1997, 315:333-7. | Article | PubMed Abstract | PubMed Full Text

8. Donahue JG, Munoz A, Ness PM, Brown DE, Jr., Yawn DH, McAllister $\mathrm{HA}$, Jr., Reitz BA and Nelson KE: The declining risk of post-transfusion hepatitis C virus infection. N Engl J Med 1992, 327:369-73. | Article | PubMed

9. Donahue JG, Nelson KE, Munoz A, Vlahov D, Rennie LL, Taylor EL, Saah AJ, Cohn S, Odaka NJ and Farzadegan $\mathrm{H}$ : Antibody to hepatitis C virus among cardiac surgery patients, homosexual men, and intravenous drug users in Baltimore, Maryland. Am J Epidemiol 1991, 134:1206-11. | Article | PubMed

10. Ko YC, Ho MS, Chiang TA, Chang SJ and Chang PY: Tattooing as a risk of hepatitis C virus infection. J Med Virol 1992, 38:288-91. | Article | PubMed

11. Tohme RA and Holmberg SD: Is sexual contact a major mode of hepatitis C virus transmission? Hepatology 2010, 52:1497-505. | Article | PubMed

12. Caiaffa WT, Zocratto KF, Osimani ML, Martinez PL, Radulich G, Latorre L, Muzzio E, Segura M, Chiparelli H, Russi J, Rey J, Vazquez E, Cuchi P, Sosa-Estani S, Rossi D and Weissenbacher M: Hepatitis $C$ virus among non-injecting cocaine users (NICUs) in South America: can injectors be a bridge? Addiction 2011, 106:143-51. | Article | PubMed

\section{Citation:}

Krystyna A, Kumari D, Tenney R, Kosanovic R, Safi T, Briggs W M, Hennessey K, Skelly M, Enriquez E, Lajeune J, Ghani $W$ and Schwalb M D: Hepatitis c antibody testing in African American and Hispanic men in New York City with prostate biopsy. Oncology Discovery 2013, 1:1. http://dx.doi.org/10.7243/2052-6199-1-1 